\title{
PROBLEMATIKA PENGEMBANGAN KARIR TENAGA PENDIDIK DI SMA NEGERI 8 KABUPATEN BATANGHARI
}

\author{
Firman Khaidir ${ }^{1}$, Sophia Rahmawati ${ }^{2}$, Fellicia Ayu Sekonda ${ }^{3}$ \\ Dosen Universitas Jambi \\ Mendalo Darat, Kec. Jambi Luar Kota, Kab. Muaro Jambi, Jambi \\ Sur-el: firman.fkip@ unja.ac.id ${ }^{1}$, sophiarahma9@gmail.com², \\ felliciaas@unja.ac.id ${ }^{3}$
}

Article info

Article history:

Received: 04-04-2020

Revised : 25-04-2020

Accepted: 27-05-2020

\begin{abstract}
A B S T R A C T
This aims of this research are to investigate teachers' problems related to the career development and to find out the benefits of training for the development of teachers' career. This research utilized qualitative method. It was conducted at SMA Negeri 8 Batanghari Regency. The research subjects were from 59 teachers. Data collection instruments consisted of observation and interview. All data were analysed descriptively. The results of this study are: Teachers already understand the writing of scientific papers which is a major obstacle in managing promotions. This effort was made in accordance with the needs of teachers in terms of knowing the guidelines for writing scientific papers which so far have not been in line with the supervisors of the Batanghari District Education Office. In addition, the obstacle faced is the motivation of teachers to conduct $C A R$ in each learning process that can be used as scientific writing material so that it can be published in the form of a journal with ISBN / ISSN standards. So that credit numbers are met for teachers to take the promotions.
\end{abstract}

Keywords:

Career Development,

Teachers, Scientific

Papers

Penelitian ini bertujuan untuk mengetahui permasalahan guru yang berkaitan dengan pengembangan karir dan mengetahui manfaat pelatihan bagi pengembangan karir guru. Penelitian ini menggunakan metode kualitatif. Pelaksanaannya di SMA Negeri 8 Kabupaten Batanghari. Subjek penelitian berjumlah 59 orang guru. Instrumen pengumpulan data terdiri dari observasi dan wawancara. Seтиа data dianalisis secara deskriptif. Hasil dari penelitian ini adalah: Pendidik sudah memahami penulisan karya ilmiah yang

Kata Kunci:

Pengembangan Karir, Pendidik, Artikel

Ilmiah merupakan kendala utama dalam mengelola promosi. Upaya ini dilakukan sesuai dengan kebutuhan pendidik dalam hal mengetahui pedoman penulisan karya ilmiah yang selama ini belum sejalan dengan pembimbing Dinas Pendidikan Kabupaten Batanghari. Selain itu, kendala yang dihadapi adalah motivasi pendidik untuk melaksanakan PTK dalam setiap proses pembelajaran yang dapat dijadikan sebagai bahan penulisan ilmiah sehingga dapat diterbitkan dalam bentuk jurnal dengan standar ISBN/ISSN. Sehingga nomor kredit terpenuhi bagi pendidik untuk mengambil promosi.

Direktorat Riset dan Pengabdian Masyarakat Universitas Bina Darma. 


\section{JURNAL ILMIAH \\ BINA EDUKASI \\ ISSN 1979-8598 E-ISSN: 2655-8378 \\ http://journal.binadarma.ac.id/index.php/jurnalbinaedukasi \\ Vol. 13, No. 1, Juni 2020, 65 -- 74}

\section{PENDAHULUAN}

Pengembangan karir merupakan salah satu tujuan dari pengembangan sumber daya manusia. Setiap individu dalam sebuah organisasi menghendaki adanya pengembangan dalam karir, yang dalam pencapaiannya menghendaki agar tiap individu dapat mempersiapkan dirinya untuk menghadapi kondisi, perubahan dan tantangan saat ini dan masa depan. Hal ini dimaksudkan dalam rangka meningkatkan daya bersaing individu dalam ketatnya persaingan di dalam maupun di luar organisasi, yang jika dapat ditingkatkan dapat berdampak pada pengembangan karir individu. Pengembangan karir pada dasarnya adalah hasil interaksi antara karir individu dengan proses manajemen karir organisasi. Harapan yang ingin di capai yaitu posisi atau kedudukan yang lebih baik dari sebelumn nya. Dalam konteks inilah dapat dikatakan bahwa karir merupakan kebutuhan setiap pegawai. Menurut Qomar (2010) pembinaan dan pengembangan pegawai pada suatu lembaga sangat dibutuhkan. Pembinaan berorientasi pada pencapaian standar minimal, yaitu diarahkan agar para pegawai dapat melakukan pekerjaannya sebaik mungkin dan menghindari pelanggaran. Sedangkan pengembangan lebih berorientasi pada pengembangan karir para pegawai.

Karir dalam kehidupan organisasional seseorang dimaksudkan sebagai semua pekerjaan dan jabatan yang dipegang oleh individu. Walaupun sulit menentukan sebuah pengembangan tentang karir individu yang bermacam-macam. Terdapat individu yang memiliki peningkatan karir berpatokan pada rancangan dan ada juga yang mendaptkan peningkatan karir dengan tidak adanya perencanaan. Untuk mengetahui pola karir yang terbuka bagi setiap orang maka perlu dipahami tiga hal yaitu: pertama, sasaran karir yang ingin dicapai; kedua, perencanaan karir dalam arti keterlibatan seseorang dalam pemilihan jalur dan sasaran karir; ketiga, kesediaan mengambil langkah-langkah yang diperlukan dalam rangka pengembangan karir sambil berkarya (Sondang, 2012). Jabatan pendidik sebagai salah satu jabatan fungsional juga menuntut adanya syarat-syarat tertentu dalam upaya pengembangan karir. Dalam Permen tersebut diatur tentang jabatan fungsional guru (pasal 12) dan jumlah angka kredit yang harus dipenuhi untuk setiap jenjang jabatan (pasal 17). Selanjutnya terbit PERBES No.14 tahun 2014 yang pada pasal 16 ayat 1 dinyatakan bahwa: "Kenaikan pangkat dapat dipertimbangkan paling sedikit dua tahun dalam pangkat terakhir", sehingga memungkinkan guru untuk dapat mengajukan kenaikan pangkat dan golongan setiap dua tahun.

Berangkat dari peraturan-peraturan tersebut, maka dapat dikatakan bahwa pengembangan karir tenaga pendidik pada lingkungan Kantor Dinas Pendidikandi provinsi Jambi belum sesuai dengan harapan ideal. Dalam kurun waktu 10 tahun terakhir terdapat beberapa tenaga pendidik yang mengalami kesulitan dalam hal kenaikan pangkat. Hal ini tidak sesuai dengan harapan 


\section{JURNAL ILMIAH \\ BINA EDUKASI \\ ISSN 1979-8598 E-ISSN: 2655-8378 \\ http://journal.binadarma.ac.id/index.php/jurnalbinaedukasi \\ Vol. 13, No. 1, Juni 2020, 65 -- 74}

karena seyogyanya dalam 2 tahun sekali tenaga pendidik telah dapat mengembangkan karirnya dalam hal kenaikan pangkat.

Hambatan bagi guru untuk mengembangkan karirnya terutama terlihat padasaat mereka inginmengurus kenaikan pangkat dari golongan III/d menuju IV/a, terutama dari golongan IV/a ke IV/b. Terdapat aturan kenaikan pangkat yang baru dimana Tenaga Pendidik yang akan naik pangkat dari Golongan III/d ke IV/a harus mengikuti kegiatan pengembangan diri baik pelatihan maupun kegiatan kelompok. Dimana terdapat 4 angka kredit yaitu berupa publikasi ilmiah/karya inovatif (karya tulis ilmiah, membuat alat peraga, alat pelajaran, karya teknologi/seni) dengan 8 angka kredit. Peraturan untuk Golongan IV/a ke IV/b harus mengikuti kegiatan berupa pengembangan diri, pelatihan dan kegiatan kelompok guru di mana besarnya 4 angka kredit dan publikasi ilmiah/karya inovatif dengan 12 angka kredit. Dari 59 orang tenaga pendidik ASN di SMA Negeri 8 Kabupaten Batanghari. mentok pada golongan IV/a pada hal tenaga pendidik ada 25 orang masa kerja sudah 20 sd. 33 tahun.

Berdasarkan hasil wawancara dengan seorang guru menyatakan bahwa: “ kesulitan saya dalam mengajukan kenaikan pangkat dikarenakan adanya aturan membuat karya tulis ilmiah disamping syarat-syarat lainnya yang dirasa cukup sulit”.Pernyataan tersebut sejalan dengan pernyataan guru lainnya yang menyatakan "Karya ilmiah memang menjadi kendala kami yang paling utama dalam mengurus kenaikan pangkat, akan tetapi itu mungkin bisa diatasi jika kami diberikan pelatihan-pelatihan terkait dengan penulisan karya ilmiah, kami sangat jarang mengikuti program-program pengembangan baik itu di sekolah maupun di Dinas Pendidikan" (Wawancara dengan guru 11 Januari 2018).

Dua pernyataan tersebut mengindikasikan bahwa kesulitan guru untuk naik pangkat dikarenakan adanya kesulitan dalam memenuhi angka kredit dan kurangnya program pelatihan dan pengembangan. Disinilah seharusnya seorang pimpinan menunjukkan perannya. Pemimpin dengan gaya kepemimpinan yang peduli terhadap kesulitan bawahan (guru) akan berupaya untuk melakukan berbagai upaya untuk membantu kesulitan para guru tersebut. Baik itu dengan menciptakan budaya organisasi yang mendukung program pengembangan karir maupun dengan selalu memotivasi guru untuk meningkatkan prestasi melalui berbagai bentuk pelatihan dan pengembangan.

Bertolak dari latar belakang dan perumusan masalah yang telah dirumuskan, maka tujuan yang diharapkan dapat dicapai dalam penelitian ini adalah untuk memperoleh informasi yang akurat mengenai kendala guru yang paling dominan dalam pengembangan karir di SMA Negeri 8 Kabupaten Batanghari. Adapun hasil penelitian ini diharapkan dapat bermanfaat dalam meningkatkan motivasi guru dalam pengembangan karirnya terutama terlihat ketika mereka akan mengurus kenaikan pangkat. Penelitian ini juga diharapkan dapat menjadi sumber acuan bagi penelitian-penelitian selanjutnya yang berguna sebagai bahan masukan berkaitan dengan 


\section{JURNAL ILMIAH \\ BINA EDUKASI \\ ISSN 1979-8598 E-ISSN: 2655-8378 \\ http://journal.binadarma.ac.id/index.php/jurnalbinaedukasi \\ Vol. 13, No. 1, Juni 2020, 65 -- 74}

perumusan kebijakan mengenai cara meningkatkan karir guru SMA di Provinsi Jambi, sebagai masukan bagi kepala SMA di Provinsi Jambi dalam rangka evaluasi diri agar mampu meningkatkan pengembangan karir guru, dan sumber motivasi tenaga kependidikan dalam mengembangkan karir.

\section{METODOLOGI PENELITIAN}

Penelitian ini bertujuan untuk mendeskripsikan pengembangan karir tenaga pendidik pada SMA Negeri 8 Kabupaten Batanghari. Metode yang digunakan dalam penelitian ini yakni metode kualitatif dengan pendekatan studi kasus.

\subsection{Sumber Data/Informan}

Data yang digunakan yakni data primer dan data sekunder. Data primer yaitu data yang didapat peneliti secara langsung dari sumber datanya yaitu kepala sekolah dan guru SMA Negeri 8 Kabupaten Batanghari. Data primer disebut juga sebagai data asli yang memiliki sifat up to date. Wujud data yang terkumpul berupa informasi lisan yang diperoleh melalui wawancara dan aktivitas yang diperoleh melalui observasi. Adapun data sekunder adalah data yang diperoleh peneliti dari berbagai sumber yang telah ada. Data sekunder dalam penelitian ini diperoleh melalui studi dokumentasi terhadap foto-foto, contoh pelatihan yang diikuti guru, piagam, dan lain-lain sesuai dengan yang dibutuhkan.

\subsection{Prosedur Pengumpulan Data}

Prosedur pengumpulan data merupakan langkah yang paling strategis dalam penelitian, karena tujuan utama dari penelitian adalah mendapatkan data. Terdapat beberapa prosedur pengumpulan data dalam penelitian studi kasus yang direkomendasikan oleh Yin (dalam Creswell, 2007), yaitu: documents, archival records, interviews, direct observation, participant observation, dan physical artifacts. Pengumpulan data dalam penelitian ini dilakukan dengan wawancara, observasi, dan studi dokumentasi.

a) Wawancara

Wawancara ini bersifat fleksibel, tidak tersusun, berupa butir pertanyaan untuk mendapatkan informasi. Peneliti memberikan pernyataan kepada informan untuk mendapatkan informasi atau permasalahan yang ditemui.

\section{b) Observasi}

Peneliti melakukan observasi terus terang dan tersamar. Observasi terus terang dilakukan ketika peneliti mewawancarai narasumber. Peneliti berterus terang kepada narasumber bahwa sedang melakukan penelitian. Observasi tersamar dilakukan ketika peneliti mengobrol dengan para siswa ketika jam istirahat atau ketika berjalan-jalan di sekitar sekolah. Observasi tersamar dilakukan untuk menghindari terjadinya tindakan yang tidak alamiah dari sumber data. 


\section{JURNAL ILMIAH \\ BINA EDUKASI \\ ISSN 1979-8598 E-ISSN: 2655-8378 \\ http://journal.binadarma.ac.id/index.php/jurnalbinaedukasi \\ Vol. 13, No. 1, Juni 2020, 65 -- 74}

Pengumpulan data melalui observasi dilakukan untuk memahami konteks data secara menyeluruh. Selain itu, dengan kegiatan observasi peneliti dapat menemukan hal-hal yang tidak terungkap saat wawancara

c) Studi Dokumentasi

Dokumen ialah setiap bahan tertulis ataupun bahan yang tidak tertulis seperti film, gambargambar, skema, struktur organisasi, dan sejenisnya. Bahan tersebut dapat digunakan sebagai sumber data dan juga dapat dimanfaatkan untuk menguji dan menafsirkan, bahkan untuk meramalkan suatu fenomena.

\subsection{Analisis Data}

Data penelitian ini diperoleh dari berbagai sumber, yaitu menggunakan teknik pengumpulan data yang bermacam-macam (triangulasi), dan dilakukan secara terus menerus sampai datanya jenuh. Menurut Miles dan Huberman (1992) menyatakan yaitukegiatan dalam analisis data kualitatif dilakukan secara komunikatif dan terus menerus hingga selesai.

\subsection{Pengecekkan Keabsahan Temuan}

Moleong (2006) mengajukan empat kriteria untuk menetapkan keabsahan data yang diperlukan dalam suatu penelitian kualitatif, yaitu sebagai berikut.

a. Derajat Kepercayaan (credibility)

Penerapan kriterium derajat kepercayaan (credibility) pada dasarnya menggantikan konsep validitas internal dari nonkualitatif. Kriterium ini berfungsi: (1) melaksanakan inkuiri sedemikian rupa sehingga tingkat kepercayaan penemuannya dapat dicapai, (2) mempertunjukkan derajat kepercayaan hasil-hasil penemuan dengan jalan pembuktian oleh peneliti pada kenyataan ganda yang sedang diteliti. Menurut Denzin (Patton, 2006) terdapat empat tipe dasar triangulasi sebagai teknik pemeriksaan untuk mencapai keabsahan, yaitu: triangulasi metode, triangulasi data, triangulasi teori, triangulasi pengamat atau investigator.

Dalam penelitian ini peneliti menggunakan triangulasi metode dan triangulasi data. Peneliti menggunakan beberapa metode berbeda seperti wawancara, observasi, dan dokumentasi dalam proses pengumpulan data. Peneliti juga mengumpulkan data dari berbagai sumber yaitu dengan mewawancarai lebih dari satu subjek yang dianggap memiliki sudut pandang yang berbeda.

\section{b. Keteralihan (Transferability)}

Kriteria keteralihan berbeda dengan validitas eksternal dalam penelitian nonkualitatif. Konsep ini menyatakan bahwa generalisasi suatu penemuan dapat berlaku atau diterapkan pada semua konteks dalam populasi yang sama atas dasar penemuan yang diperoleh pada sampel yang secara representatif mewakili populasi itu. Kriteria kebergantungan adalah substitusi istilah reliabilitas dalam penelitian nonkualitatif. Konsep kebergantungan lebih luas daripada reliabilitas. Hal tersebut disebabkan oleh peninjauannya dari segi bahwa konsep itu memperhitungkan segala-galanya, yaitu yang ada pada reliabilitas itu sendiri ditambah faktor-faktor lainnya. Dalam 


\section{JURNAL ILMIAH \\ BINA EDUKASI \\ ISSN 1979-8598 E-ISSN: 2655-8378 \\ http://journal.binadarma.ac.id/index.php/jurnalbinaedukasi \\ Vol. 13, No. 1, Juni 2020, 65 -- 74}

penelitian ini, keajegan mengacu pada kemungkinan peneliti selanjutnya memperoleh hasil yang sama apabila penelitian dilakukan sekali lagi dengan subjek yang sama. Hal ini menujukkan bahwa konsep keajegan penelitian kualitatif selain menekankan pada desain penelitian, juga pada cara pengumpulan data dan pengolahan data.

c. Kepastian (Confirmability)

Kriteria kepastian berasal dari konsep objektivitas menurut nonkualitatif. Sesuatu hal dapat dikatakan objektif apabila dapat dipercaya, faktual, dan dapat dipastikan.Konsep ini merujukpada seberapa jauh kesimpulan hasil penelitian menggambarkan keadaan yang sesungguhnya. Keabsahan ini dapat dicapai melalui proses analisis dan interpretasi yang tepat. Aktivitas dalam melakukan penelitian kualitatif akan selalu berubah dan tentunya akan mempengaruhi hasil dari penelitian tersebut. Walaupun telah dilakukan uji keabsahan internal, tetap ada kemungkinan munculnya kesimpulan lain yang berbeda.

\section{HASIL DAN PEMBAHASAN}

Problematika pengembangan karir bagi guru tersebut meliputi: kurangnya pemahaman tentang penulisan karya ilmiah; pedoman penulisan karya ilmiah yang tidak sejalan dengan pengawas Dinas Pendidikan Kabupaten; dan hambatan guru dalam menulis karya tulis ilmiah dan pemahaman mengenai pengembangan kompetensi profesional. Berbagai kendala dan problematika pengembangan karir berikut ini.

\subsection{Kurangnya Pemahaman Penulisan Karya Ilmiah}

Permasalahan utama dalam problematika pengembangan karir bagi guru dalam menulis karya ilmiah sebagai pengembangan kompetensi professional, memberikan rasa ingin tahu bagi guru untuk mengetahui bagaimana kemampuan guru dalam menulis karya ilmiah; pemahaman guru mengenai pengembangan kompetensi professional; hambatan guru dalam menulis karya Ilmiah sebagai pengembangan kompetensi professional.

Diharapkan semua pihak yang berada dalam lingkup pendidikan dapat mengetahui bahwa sebenarnya kemampuan menulis karya ilmiah guru dapat dijadikan ke dalam salah satu kegiatan pengembangan kompetensi professional. Terdapat guru yang belum memahami penulisan karya

ilmiah untuk syarat mengurus kenaikan pangkat bagi guru di SMA Negeri 8 Kabupaten Batanghari.

Pendapat dari Ibu HDA yaitu guru masih kesulitan dalam membuat karya tulis ilmiah. Menjadi tolak ukur yang mendasar dimana terdapat guru yang tidak pernah sama sekali menulis karya tulis ilmiah. Karya ilmiah merupakan tulisan bedasarkan dengan kaidah penulisan, sesuai permasalahan, realita di lapangan, dan dapat dipertanggungjawabkan. Sesuai dengan yang 


\section{JURNAL ILMIAH \\ BINA EDUKASI \\ ISSN 1979-8598 E-ISSN: 2655-8378 \\ http://journal.binadarma.ac.id/index.php/jurnalbinaedukasi \\ Vol. 13, No. 1, Juni 2020, 65 -- 74}

diungkapkan Kunandar (2013:27), bahwa ciri karya ilmiah adalah mengikuti metode keilmuan, runtut, sistematis, dan akurat atau teliti,objektif, lugas, dan dapat dipercaya,dapat dikaji atau diteliti ulang dan dibuktikan,terbuka untuk umum.

\subsection{Pedoman Penulisan Karya Ilmiah}

Salah satu faktor penghambat bagi guru menurut pendapat ES, yaitu salah satunya tidak ada persamaan persepsi dalam Pedoman penulisan karya ilmiah antara guru dan pengawas di Dinas Pendidikan Kabupaten Batanghari, yang mengakibatkan guru kesulitan dalam menulis karya ilmiah. Pedoman penulisan karya ilmiah juga merupan komponen yang penting. Sehingga memudahkan guru mengetahui sistematika penulisan karya ilmiah dan berkonsultasi dengan pengawas. Tetapi semenjak peralihan SMA dari Dinas Kabupaten Kota Jambi ke Dinas Pendidikan Provinsi Jambi prosesnya lebih mudah dan cepat proses bimbingan penulisan karya ilmiah. Seperti yang diungkapkan oleh Arifin (2003) yaitu karangan ilmu pengetahuan yang menyajikan fakta dan ditulis menurut metodologi penulisan yang baik dan benar, artinya pengungkapan permasalahan dalam karya ilmiah itu harus berdasarkan fakta, bersifat objektif, emosional dan personal serta disusun secara sistematis dan logis. Bahasa yang digunakan adalah Bahasa Indonesia ragam baku dengan memperhatikan kaidah EYD dan pembentukan istilah.

\subsection{Hambatan Guru dalam Menulis Karya Ilmiah}

Hambatan dalam menulis karya ilmiah yang paling dominan dirasakan oleh para guru SMA Negeri 8 Kabupaten Batanghari yang ditegaskan oleh pernyataan Kepala Sekolah adalah adanya keterbatasan waktu. Kondisi guru SMA Negeri 8 Kabupaten Batanghari yang dirasakan yaitu terbatasnya waktu, karena tuntutan administrasi pembelajaran dan beban mengajar yang padat. Hasil temuan hambatan dari segi waktu yang telah dijelaskan di atas, sesuai dengan hasil temuan penelitian yang dilakukan oleh Larasati (2014) bahwa kondisi guru di SD tersebut juga mengungkapkan bahwa terbatasnya waktu dikarenakan tuntutan administrasi pembelajaran serta jam mengajar guru yang padat. Sedangkan menurut para guru untuk bisa menulis karya ilmiah haruslah membutuhkan waktu yang cukup dan sedang tidak disibukkan oleh tugas yang lainnya.

Rendahnya motivasi guru di SMA Negeri 8 Kabupaten Batanghari karena faktor usia.dan belum adanya pihak terutama pihak sekolah yang memberikan pelatihan pada guru yang berkaitan dengan penulisan karya ilmiah. Hal ini sesuai dengan pendapat Marijan (2012) bahwa faktor penghambat kegiatan menulis ada dua, yaitu faktor internal dan faktor eksternal. Faktor usia merupakan hambatan yang berasal dari dalam diri guru atau faktor internal. Sedangkan faktor belum adanya pelatihan dari pihak sekolah merupakan faktor yang berasal dari luar guru atau disebut juga faktor eksternal. 


\section{JURNAL ILMIAH \\ BINA EDUKASI \\ ISSN 1979-8598 E-ISSN: 2655-8378 \\ http://journal.binadarma.ac.id/index.php/jurnalbinaedukasi \\ Vol. 13, No. 1, Juni 2020, 65 -- 74}

\section{SIMPULAN}

Berdasarkan hasil penelitian yang telah dipaparkan pada bab sebelumnya maka dapat dijelaskan bahwa dalam aturan kenaikan pangkat yang baru disebutkan bahwa tenaga pendidik wajib melaksanakan kegiatan pengembangan diri (pelatihan dan kegiatan kolektif guru) dan publikasi ilmiah/karya inovatif (karya tulis ilmiah, membuat alat peraga, alat pelajaran, karya teknologi/seni). Selanjutnya wajib publikasi ilmiah/karya inovatif (karya tulis ilmiah, membuat alat peraga, alat pelajaran, karya teknologi/seni).

Problematika pengembangan karir ini bagi guru bukan menjadi momok yang menakutkan. Sesuai dengan PERBES No.14 tahun 2014 yang pada pasal 16 ayat 1 dinyatakan bahwa: "Kenaikan pangkat dapat dipertimbangkan paling sedikit dua tahun dalam pangkat terakhir", sehingga memungkinkan guru untuk dapat mengajukan kenaikan pangkat dan golongan setiap dua tahun. Upaya guru SMA Negeri 8 Kabupaten Batanghari dalam pengembangan karir Penulisan karya tulis ilmiah sesuai pedoman penulisan karya tulis ilmiah.

Ada dua faktor yang memengaruhi proses pengembangan karir pendidik di SMA Negeri 8 Kabupaten Batanghari. Faktor pendukungnya, ialah adanya motivasi baik dari diri sendiri ataupun kelompok dari guru SMA Negeri 8 Kabupaten Batanghari untuk menulis karya tulis ilmiah dalam pengembangan karir. Adapun, faktor penghambat yang dihadapi oleh guru SMA Negeri 8 Kabupaten Batanghari yaitu kurangnya pemahaman tentang penulisan karya ilmiah, pedoman penulisan karya ilmiah yang tidak sejalan dengan pengawas Dinas Pendidikan Kabupaten, serta hambatan guru dalam menulis karya tulis ilmiah dan pemahaman mengenai pengembangan kompetensi profesional.

\section{DAFTAR PUSTAKA}

Arifin. (2003). Memahami Paradigma Baru Pendidikan Nasional dalam Undangundang Sisdiknak. Catatan ketiga. Jakarta: Ditjen Kelembagaan Agama Islam.

Creswell, J.W. (2007). Qualitative Inquiry \& Research Design: Choosing among Five Approaches. $2^{\text {nd }}$ Edition. California: Sage.

Kunandar. (2013). Penilaian Authentik: Penilaian Hasil Belajar Peserta Didik Berdasarkan Kurikulum 2013. Jakarta: Rajawali Pers.

Larasati, Rahma Titi. (2014). Faktor-Faktor Penghambat Penulisan Karya Tulis Ilmiah Dalam Pengembangan Keprofesian Berkelanjutan Guru SDN Lempuyangwangi Yogyakarta. https://eprints.uny.ac.id/13854/. Diunduh pada 14 April 2020.

Marijan. (2012). Cara Gampang Pengembangan Profesi Guru. Yogyakarta : Sabda Media. 


\section{JURNAL ILMIAH}

BINA EDUKASI

ISSN 1979-8598 E-ISSN: 2655-8378

http://journal.binadarma.ac.id/index.php/jurnalbinaedukasi

Vol. 13, No. 1, Juni 2020, 65 -- 74

Miles dan Huberman. (1992). Analisis data Kualitatif. Terjemahan Tjetjep Rohedi Rosidi. (2005) Jakarta: Universitas Indonesia.

Moleong, L. J. (2014). Metodologi penelitian Kualitatif. Bandung: PT Remaja Rosdakarya.

Qomar. (2010). Manajemen Pendidikan Islam, Strategi Baru Pengelolaan Lembaga Pendidikan Islam. Jakarta: Erlangga.

Sondang P. Siagian. (2008). Manajemen Sumber Daya Manusia, Jakarta: Bumi Aksara.

Patton, Michael Quinn. (2006). Metode Evaluasi Kualitatif. Yogyakarta: Pustaka Pelajar.

Peraturan Bersama Mendiknas dan Kepala BKN Nomor 03/V/PB/2010, tentang Petunjuk Pelaksanaan Jabatan Fungsional Guru dan Angka Kreditnya.

Peraturan Bersama Mendiknas dan Kepala BKN Nomor 14 tahun 2014, tentang Petunjuk Pelaksanaan Jabatan Fungsional Guru dan Angka Kreditnya.

Peraturan Menteri Pendayagunaan Aparatur Negara dan Reformasi Birokrasi (Permen PANRB) Nomor 16 tahun 2009 tanggal 10 November 2009, tentang Jabatan Fungsional Guru dan Jumlah Angka Kredit.

Peraturan Menteri Pendidikan Nasional Nomor 28 tahun 2010 tentang Penugasan Guru sebagai Kepala Sekolah/Madrasah. 